УДК 634.8:632.4

DOI 10.30679/2219-5335-2022-1-73-222-232

РАСПРОСТРАНЕНИЕ МИЛДЬЮ НА ВИНОГРАДНЫХ РАСТЕНИЯХ ДОНСКОЙ АМПЕЛОГРАФИЧЕСКОЙ КОЛЛЕКЦИИ

\author{
Арестова Наталья Олеговна \\ канд. с.-х. наук, доцент \\ ведущий научный сотрудник \\ группы защиты растений \\ от болезней и вредителей \\ e-mail: zash.arestova@yandex.ru \\ Рябчун Ирина Олеговна \\ канд. с.-х. наук \\ заместитель директора \\ по научной работе \\ e-mail: ruswiner@mail.ru \\ Рябущенко Наталья Григорьевна \\ аспирант
}

Всероссийский научно-исследовательский институт виноградарства

и виноделия имени Я.И. Потапенко -

филиал Федерального государственного

бюджетного научного учреждения

«Федеральный Ростовский

аграрный научный центтр»,

Новочеркасск, Россия

Приводятся результаты исследований об интенсивности развития милдью в условиях виноградников Донской ампелографической коллекции в 2019-2021 гг. Сохранению зимующих форм милдью способствовали погодные условия периодов покоя в 2019-2021гг.: отсутствие низких отрицательных температур и достаточная влажность воздуха (61-85 \%). Температура воздуха в осенне-зимние периоды в годы исследований была существенно выше среднемноголетних значений (сумма отрицательных температур составляла от $119,4^{\circ} \mathrm{C}$ до $274,3^{\circ} \mathrm{C}$ ). При таких условиях ооспоры патогена,
UDC 634.8:632.4

DOI 10.30679/2219-5335-2022-1-73-222-232

DISTRIBUTION OF DOWNY MILDEW

ON GRAPE PLANTS

OF THE DON AMPELOGRAPHIC COLLECTION

Arestova Natalya Olegovna

Cand. Agr. Sci., Docent

Leading Research Associate

of Plant Protection from Diseases

and Vermins GrouP

e-mail: zash.arestova@yandex.ru

Ryabchun Irina Olegovna

Cand. Agr. Sci.

Deputy Chief

for Research Work

e-mail: ruswiner@mail.ru

Ryabushchenko Natalia Grigorievna Postgraduate Student.

\section{All-Russian Research}

Institute named after Ya.I. Potapenko

for Viticulture and Wine-making-

Branch of Federal State

Budget scientific Institution

«Federal Rostov Agricultural

Research Center»,

Novocherkassk, Russia

The results of studies on the intensity of downy mildew development in the conditions of the vineyards of the Don ampelographic collection in 2019-2021 are presented.

The preservation of wintering forms of mildew was facilitated by the weather conditions of the dormant periods $i$ n 2019-2021: the absence of low freezing temperatures and sufficient humidity (61-85\%). The air temperature in the autumn-winter periods during the years of research was significantly higher than the average long-term values (the sum of negative temperatures ranged 
прорастая в начале вегетации, производят инокулят для первичного инфицирования растений.

Фитомониторинг пораженности различных сортов милдью в эпифитотийных условиях 2021 г. позволил выделить наиболее устойчивые сорта для их дальнейшего использования в качестве доноров милдьюустойчивости. В периоды вегетации в 2019, 2020 гг. повышенная температура, по сравнению со среднемноголетними значениями, и низкая влажность способствовали депрессивному развитию милдью. При гидротермическом коэффициенте от 0 до 0,5 у растений $70-80 \%$ сортов признаки милдью отсутствовали. Интенсивность развития заболевания у остальных сортов не превышала 2,5 балла. В 2021 г. во все месяцы вегетации, за исключением июля, наблюдался недобор осадков.

Несмотря на это, повышенная влажность воздуха в мае-июле при гидротермическом коэффициенте 0,8-1,2 способствовала интенсивному развитию милдью. В результате у $12 \%$ сортов Донской ампелографической коллекции выявили наибольшую устойчивость к милдью (до 2 баллов): Тавроси; Початочный; Ольховский; Накутвнеули; Косоротовский; Грдзелмтевана. Интенсивность поражения от 2 до 3,5 баллов выявили у $78 \%$ сортов. Наименьшая устойчивость к милдью (более 3,5 баллов) проявилась у $10 \%$ сортов: Сыпун черный; Пухляковский черный; Меграбуйр; Бессергеневский № 1; Белобуланый.

Ключевые слова: ВИНОГРАД, МЕТЕОРОЛОГИЧЕСКИЕ УСЛОВИЯ, МИЛДЬЮ, РАСПРОСТРАНЕННОСТЬ, ИНТЕНСИВНОСТЬ РАЗВИТИЯ from $119.4{ }^{\circ} \mathrm{C}$ to $274.3{ }^{\circ} \mathrm{C}$ ). Under such conditions, the oospores of the pathogen, germinating at the beginning of the growing season, produce an inoculum for primary infection of plants. Phytomonitoring of the infestation of various varieties with downy mildew under epiphytotic conditions in 2021 made it possible to identify the most resistant varieties for their further use as donors of downy mildew resistance. During the growing seasons in 2019, 2020, the increased temperature, compared with the average annual values, and low humidity contributed to the depressive development of downy mildew. When the hydrothermal coefficient was from 0 to 0.5 , the plants of $70-80 \%$ of varieties had no signs of downy mildew. The intensity of disease development in other varieties did not exceed 2.5 points. In 2021, in all growing months, with the exception of July, there was a shortage of precipitation. Despite this, the increased air humidity in May-July with a hydrothermal coefficient of 0.8-1.2 contributed to the intensive development of downy mildew. As a result, $12 \%$ of the varieties of the Don ampelographic collection showed the highest resistance to downy mildew (up to 2 points):

Tavrosi; Pochatochnyy; Ol'khovskiy; Nakutvneuli; Kosorotovskiy; Grdzelmtevana. The intensity of the infestation from 2 to 3.5 points was found in $78 \%$ of the varieties. The least resistance to downy mildew (more than 3.5 points) was manifested in $10 \%$ of varieties: Sypunchernyy; Pukhlyakovskiy chernyy; Megrabuyr; Bessergenevskiy № 1; Belobulanyy.

Key words: GRAPES, METEOROLOGICAL CONDITIONS, DOWNY MILDEW, PREVALENCE, INTENSITY OF DEVELOPMENT 
Введение. Одним из самых серьезных заболеваний винограда, приводящих к большим экономическим потерям при производстве винограда, является милдью или ложная мучнистая роса (Plasmopara viticola). На виноградниках Европы возбудитель заболевания стал распространяться со второй половины 19 века, на рубеже 19 и 20 веков заболевание появилось на Дону. В годы эпифитотийного развития милдью потери урожая могут существенно превышать 50 \% [1-3]. Ряд авторов указывает на то, что существуют популяции Plasmopara viticola различной степени вирулентности [4-6].

Интенсивность развития фитопатогена в большей степени зависит от метеорологических условий вегетационного периода $[7,8]$. Размножение патогена осуществляется с помощью спор при высокой влажности воздуха и температуре воздуха не ниже $12^{\circ} \mathrm{C}$. Оптимальными условиями для размножения возбудителя милдью является температура воздуха $20-25{ }^{\circ} \mathrm{C}$ и влажность 61-85 \% [9]. При заражении милдью на листьях образуются желтые, маслянисто прозрачные пятна. У молодых листьев наблюдается осветление пораженных тканей листьев, у более старых листьев пятна расположены, как правило, вдоль жилок. При влажной теплой погоде на нижней стороне листьев под пятнами появляется белый налет, представляющий грибницу патогена. Милдью могут поражаться не только листья, но и остальные зеленые части куста, включая верхушки побегов, усики, соцветия, гребни и молодые ягоды винограда [10]. Зараженные соцветия винограда желтеют и деформируются, а затем буреют и засыхают. Ягоды также окрашиваются в бурый цвет, сморщиваются и становятся непригодными для дальнейшего использования. Также известно, что условия перезимовки в значительной степени влияют на созревание и прорастание ооспор милдью, которые позволяют патогену выжить в состоянии покоя виноградной лозы и, прорастая, производить инокулят для первичного инфицирования растений $[11,12]$.

Особенно восприимчивы к заражению молодые завязи после опадения цветков, поэтому химическая обработка до и после цветения может существенно уменьшить интенсивность их поражения патогеном. 
Интенсивность развития милдью у виноградных растений в определенной степени зависит от их сортовых особенностей [13-16]. Несмотря на то, что ни один из сортов Vitis vinifera не обладает высокой устойчивостью к патогену, степень их толерантности различна [17]. В связи с этим целью наших исследований являлся фитомониторинг пораженности различных сортов патогеном в условиях Донской ампелографической коллекции, выделение наиболее устойчивых для их дальнейшего использования в качестве доноров милдьюустойчивости.

Объекты и методы исследования. Исследования проводились на базе Новочеркасского отделения опытного поля ВНИИВиВ - филиала ФГБНУ ФРАНЦ. Объектами исследования являлись многолетние виноградные растения разных сортов Донской ампелографической коллекции, культивируемые с укрытием на зиму. Площадь питания кустов $-3 \times 1,5$ м, форма куста - длиннорукавная.

Обследование виноградных насаждений проводились по методике П.Н. Недова [18].

Степень поражения сортов и оценка их устойчивости определялись по общепринятым методикам $[19,20]$. Для оценки фитосанитарного состояния растений использовали пятибалльную шкалу с учетом видимых симптомов заболевания:

1 балл - единичные пятна;

2 балла - поражено до 10 \% площади зеленых органов;

3 балла - поражено до 25 \% листьев или генеративных органов;

4 балла - поражено 25-50 \% площади зеленых органов;

5 баллов - поражение свыше $50 \%$ с некрозом тканей и опадением листьев.

Анализ метеорологических условий осуществляли на основе данных метеопоста ВНИИВиВ - филиала ФГБНУ ФРАНЦ. 
Плодоводство и виноградарство Юга России № 73(1), 2022 г.

Растения исследуемых сортов на ампелоколлекции имеют в основном техническое направление использования (за исключением универсальных сортов - Бургундский, Галан, Косоротовский, Кабашный, Крестовский, Мушкетный, Старый горюн, Пухляковский белый, Ольховский, Кумшацкий белый; столовых - Бурый, Ефремовский, Пухляковский черный, Шасла белая) и относятся к разным срокам созревания, укрываются на зиму.

Интенсивность поражения растений болезнью оценивали на 7 день после химической обработки и перед очередным опрыскиванием.

Расход фунгицидов осуществляли на основании норм, приведенных в государственном каталоге пестицидов, разрешенных к применению на территории РФ.

Обсужндеие результатов. Решающее влияние на интенсивность развития фитопатогенов оказывают метеорологические условия. Метеорологические условия периодов покоя в 2019-2021 г. способствовали сохранению зимующих форм милдью. В этот период средняя сумма отрицательных температур была меныше среднемноголетних значений на 161,4 ${ }^{\circ} \mathrm{C}$ (в 2019 г.), на $274,3{ }^{\circ} \mathrm{C}$ в 2020 г., на $119,4{ }^{\circ} \mathrm{C}$ в 2021 г. Осадков в период покоя выпало в 2019 г. на 39,4 мм меньше средних значений, что составило 85,1 \% нормы, в 2020 г. - на 101,2 мм (61 \%), в 2021 г. - на 103 мм (62 \%) (табл. 1).

Таблица 1 - Метеорологические условия в период покоя в 2019-2021 гг.

\begin{tabular}{|l|l|l|l|l|l|l|l|l|l|}
\hline \multirow{3}{*}{ Месяцы } & \multicolumn{8}{|c|}{ Отклонение от среднемноголетних значений } \\
\cline { 2 - 11 } & $\begin{array}{c}\text { Средние температуры } \\
\text { воздуха, }{ }^{\circ} \mathrm{C}\end{array}$ & $\begin{array}{c}\text { Сумма отрицательных } \\
\text { среднесуточных } \\
\text { температур воздуха, }{ }^{\circ} \mathrm{C}\end{array}$ & \multicolumn{3}{c|}{ Осадки, мм } \\
\cline { 2 - 11 } & $2019 г$ & $2020 г$ & $2021 \Gamma$ & $2019 \Gamma$ & 2020 г & 2021 г & $2019 \Gamma$ & $2020 г$ & $2021 \Gamma$ \\
\hline Октябрь & $+4,2$ & $+3,3$ & $+3,3$ & & $+3,1$ & & $-15,3$ & $-26,1$ & $-21,3$ \\
\hline Ноябрь & $-1,8$ & $+1,4$ & $+1,4$ & $+46,1$ & $+30,3$ & $+14,9$ & $+2,8$ & $-4,0$ & $-24,6$ \\
\hline Декабрь & $+0,8$ & $+3,9$ & $+3,9$ & $-12,5$ & $-57,5$ & $+36,2$ & $+22,7$ & $-42,6$ & $-41,4$ \\
\hline Январь & $+2,8$ & $+5,9$ & $+5,9$ & $-73,1$ & $-141,6$ & $-71,8$ & $-1,0$ & $-34,3$ & $-17,9$ \\
\hline Февраль & $+3,3$ & $+4,4$ & $+4,4$ & $-93,9$ & $-83,4$ & $-95,5$ & $+10,7$ & $+37,3$ & $-28,3$ \\
\hline Март & $+3,8$ & $+6,7$ & $+6,7$ & $-25,5$ & $-25,2$ & $-3,2$ & $+7,3$ & $-31,5$ & $+30,5$ \\
\hline Всего & & & & $-158,9$ & $-274,3$ & $-119,4$ & $-36,2$ & $-101,2$ & $-103,0$ \\
\hline
\end{tabular}


Во все годы исследований (2019-2021 гг.) сумма активных температур в периоды вегетации превышала среднемноголетние показатели, а сумма осадков была меньше нормы. При этом гидротермический коэффициент, показывающий степень увлажненности территории и составляющий для Ростовской области в среднем 0,7, варьировал по месяцам, что свидетельствует о чередовании засушливых и увлажненных периодов (табл. 2).

Таблица 2 - Метеорологические условия в период вегетации в 2019-2021 гг.

\begin{tabular}{|c|c|c|c|c|c|c|c|c|c|}
\hline \multirow{3}{*}{ Месяцы } & \multicolumn{6}{|c|}{ Отклонение от среднемноголетних значений } & \multirow{2}{*}{\multicolumn{3}{|c|}{$\begin{array}{c}\text { Гидротермический } \\
\text { коэффициент }\end{array}$}} \\
\hline & \multicolumn{3}{|c|}{$\begin{array}{c}\text { средние температуры } \\
\text { воздуха, }{ }^{\circ} \mathrm{C}\end{array}$} & \multicolumn{3}{|c|}{ сумма осадков, мм } & & & \\
\hline & 2019 г. & 2020 г. & $2021 г$. & $2019 \Gamma$. & 2020 г. & $2021 \Gamma$ & $2019 \Gamma$ & 2020 г. & $2021 \Gamma$ \\
\hline Апрель & $+0,9$ & $-1,1$ & $-0,5$ & $-1,9$ & $-26,1$ & $-3,1$ & 1,0 & 0,4 & 1,2 \\
\hline Май & $+1,9$ & $-1,6$ & $+1,1$ & $+13,9$ & $-0,1$ & $-1,1$ & 1,1 & 1,0 & 0,8 \\
\hline Июнь & $+4,3$ & $+2,4$ & $+0,8$ & $-47,5$ & $-32,7$ & $-3,3$ & 0,2 & 0,4 & 0,9 \\
\hline Июль & $-0,9$ & $+2,0$ & $+2,6$ & $-13,7$ & $-1,7$ & $+21,7$ & 0,4 & 0,5 & 0,9 \\
\hline Август & $+1,0$ & $+1,0$ & $+3,5$ & $-24,2$ & $-32,1$ & $-14,3$ & 0,2 & 0,1 & 0,3 \\
\hline Сентябрь & $+0,6$ & $+3,5$ & $-0,9$ & $-24,5$ & $-37,5$ & $-20,1$ & 0,3 & 0 & 0,4 \\
\hline За период & & & & $-97,9$ & $-130,2$ & $-18,2$ & & & \\
\hline
\end{tabular}

Метеорологические наблюдения свидетельствуют о том, что во все годы исследований (2019-2021 гг.) в фазе «до цветения» (в мае) наблюдалась повышенная влажность, что подтверждается величиной гидротермического коэффициента от 0,8 до 1,1. Проведенные в это период защитные мероприятия позволили сдерживать развитие милдью. В 2019-2020 гг. в остальные фазы вегетации наблюдались засушливые периоды, когда гидротермический коэффициент составлял от 0 до 0,5 , что сдерживало развитие фитопатогена. В 2021 г. превышение количества осадков по сравнению со среднемноголетними значениями наблюдалось только в июле. Хотя в среднем за вегетацию их недобор составил 103 мм, повышенная влажность в первой половине вегетации, о чем свидетельствует величина гидротермического коэффициента от 0,8 до 1,2 , способствовала развитию болезни. В таблице 3 приведены данные по интенсивности развития болезни за 3 года у различных сортов винограда. 
Плодоводство и виноградарство Юга России № 73(1), 2022 г.

Таблица 3 - Интенсивность развития милдью на виноградных растениях в условиях Донской ампелоколлекции, 2019-2021 гг.

\begin{tabular}{|c|c|c|c|}
\hline Copт & 2019 г. & 2020 г. & $2021 \Gamma$. \\
\hline Безымянный донской & 0 & 0 & 4,5 \\
\hline Белобуланый & 0 & 0 & 3,6 \\
\hline Бессергеневский № 1 & 0 & 1,2 & 3,8 \\
\hline Бессергеневский № 3 & 0 & 1,2 & 2,4 \\
\hline Бессергеневский № 5 & 0 & 1,3 & 2,6 \\
\hline Бессергеневский № 7 & 0 & 0 & 2,6 \\
\hline Бессергеневский № 10 & 0 & 0 & 2,6 \\
\hline Бургундский & 0 & 0 & 2,5 \\
\hline Бурый & 1,2 & 0,5 & 2.6 \\
\hline Варюшкин & 0 & 1,1 & 2,2 \\
\hline ВИР-1 & 0 & 0 & 3,5 \\
\hline Галан & 0 & 0 & 2,6 \\
\hline Грдзелмтевана & 0 & 0 & 2,0 \\
\hline Димацкун & 1,8 & 1,3 & 2,8 \\
\hline Дурман & 0 & 1,2 & 3,4 \\
\hline Ефремовский & 0 & 0 & 2,1 \\
\hline Кабашный & 0 & 0 & 2.8 \\
\hline Каберне Совиньон & 0 & 0 & 3,4 \\
\hline Косоротовский & 0 & 1,0 & 1,2 \\
\hline Красностопзолотовск. & 0 & 1,2 & 2,4 \\
\hline Крестовский & 0 & 0 & 2,4 \\
\hline Кумшацкий белый & 0 & 0 & 2,4 \\
\hline Кумшацкий черный & 0 & 0 & 2,4 \\
\hline Махроватчик & 0 & 0 & 2,1 \\
\hline Меграбуйр & 0 & 0 & 3,6 \\
\hline Мушкетный & 0 & 0 & 2,8 \\
\hline Накутвнеули & 0 & 0 & 1,9 \\
\hline Неизвестный донской & 1,6 & 1,1 & 2,8 \\
\hline Ольховский & 0 & 1,1 & 1,8 \\
\hline Плечистик & 0 & 0 & 2,6 \\
\hline Плечистик обоеполый & 0 & 0 & 3,1 \\
\hline Початочный & 0 & 0 & 1,6 \\
\hline Пухляковский белый & 0 & 0 & 2,1 \\
\hline Пухляковский черный & 1.0 & 0 & 3,6 \\
\hline Рислинг рейнский & 0 & 0 & 3,3 \\
\hline Сибирьковый & 0 & 0 & 3,2 \\
\hline Сиволистный & 0 & 1,3 & 2,9 \\
\hline Сильняк & 0 & 0 & 3,1 \\
\hline Слитной & 0 & 0 & 2,6 \\
\hline Старый горюн & 0 & 0 & 2,5 \\
\hline Сыпун черный & 0 & 0 & 3,6 \\
\hline Тавроси & 0 & 1,0 & 1,6 \\
\hline Ташкентский & 0 & 0 & 2,6 \\
\hline Цимладар & 1,6 & 0 & 2,8 \\
\hline Цимлянский белый & 1,0 & 0 & 2,8 \\
\hline Цимлянский Сергиенко & 1,6 & 1,1 & 3,4 \\
\hline Цимлянский черный & 1,9 & 2,2 & 3,1 \\
\hline Шампанчик - 2 & 1,5 & 1,2 & 3,4 \\
\hline Шампанчик цимлянский & 2,0 & 0 & 2,6 \\
\hline Шасла белая & 0 & 0 & 2,3 \\
\hline
\end{tabular}


Исследования показали, что в условиях Донской ампелографической коллекции наименее устойчивыми к милдью сортами (пораженность более 3,5 баллов) являются: Сыпун черный; Пухляковский черный; Меграбуйр; Бессергеневский № 1; Белобуланый, что составило $10 \%$. Интенсивность поражения от 2 до 3,5 баллов выявили у 78 \% сортов. Наибольшую устойчивость к милдью (до 2 баллов) показали сорта: Тавроси; Початочный; Ольховский; Накутвнеули; Косоротовский; Грдзелмтевана (12 \%).

Милдью активно развивалась в фазе роста, когда устьица у ягод уже закрылись, поэтому белый налет спороношения наблюдали только на листьях (рис. 1)

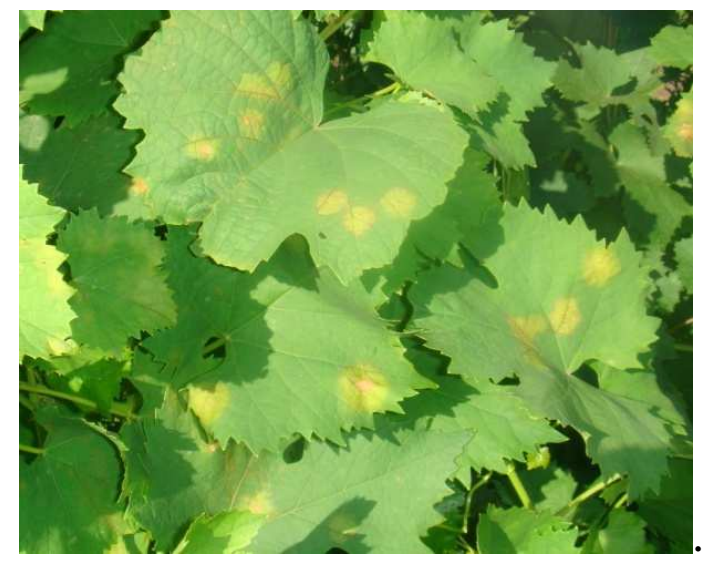

A

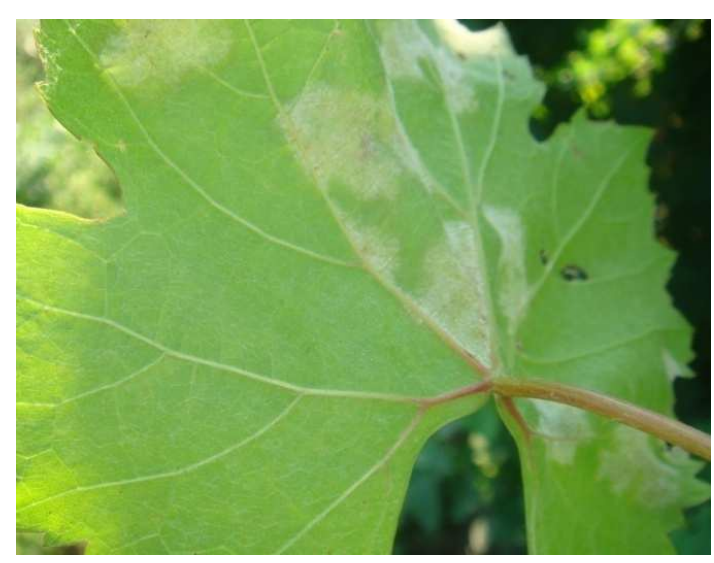

Б

Рис. 1. Спороношение милдью на листьях (А - на верхней, Б - на нижней сторонах)

Повреждений фитопатогеном остальных органов виноградных растений мы не наблюдали.

Bbыводы. Депресивное развитие милдью наблюдалось в 2019, 2020 гг, эпифитотийное - в 2021 гг.

Несмотря на пониженное количество осадков в период вегетации 2021 г, по сравнению со среднемноголетними значениями, интенсивность развития заболевания у восприимчивых сортов превышала 3,5 балла. Это связано с повышенной влажностью в первой половине вегетации, до начала созревания ягод, что подтверждается повышенным показателем гидротермического коэффициента $(0,8-1,2)$. 
Плодоводство и виноградарство Юга России № 73(1), 2022 г.

Из наблюдаемых 50 сортов Донской ампелографической коллекции наибольшей устойчивостью к милдью (до 2 баллов) отличались сорта: Тавроси, Початочный, Ольховский, Накутвнеули, Косоротовский, Грдзелмтевана, что составило $12 \%$.

Сорта Сыпун черный; Пухляковский черный; Меграбуйр; Бессергеневский № 1; Белобуланый были наиболее восприимчивы к милдью с интенсивность поражения свыше 3,5 балла, что составило 10 \% от общего количества. $78 \%$ сортов имели интенсивность поражения милдью от 2 до 3,5 баллов.

\section{Литература}

1. Шадура Н.И., Странишевская Е.П., Володин В.А. Вредоносность милдью и сортовая устойчивость на сортах винограда с различной степенью восприимчивости в условиях южнобережного агроклиматического района Республики Крым (Юг России) // Проблемы развития АПК региона. 2016. №1 (25). Ч. 1. С. 95-99.

2. Якушина Н.А., Странишевская Е.П., Гыренкова Я.Э., Скориков А.С. Защита винограда от милдью, оидиума, серой гнили в годы эпифитотийного развития // Труды научного центра виноградарства и виноделия. 2000. Т. II, кн. 1. С. 69-76.

3. Gessler C., Pertot I., Perazzolli M. Plasmoparavitícola: a review of knowledge on downy mildew of grapevine and effective disease management // Phytopathologia Mediterranea. 2011. Vol. 50. P. 3-44.

4. Boso S., Gago P., Santiago J.-L., Fuente M. and etc. Affecting the Vineyard Populational Diversity of Plasmopara viticola // Plant Pathol J. 2019. 35(2). P.125-136/

5. Delmas C., Fabre F, Jolivet J, and etc. Adaptation of a plant pathogen to partial host resistance: selection for greater aggressiveness in grapevine downy mildew // Evolutionary Applications. 2016. V. 9. P. 709-725.

6. Li X., Yin L., Ma L. and etc. Pathogenicity variation and population genetic structure of Plasmopara viticola in China. Journal of Phytopathology. 2016. 164. P. 863-873.

7. Арестова Н.О., Рябчун И.О. Развитие фитопатогенов виноградных растений в условиях Ростовской области [Электронный ресурс] // Плодоводство и виноградарство Юга России. 2016. № 42(6). С. 111-118. URL: http://journalkubansad.ru/pdf/16/06/11.pdf. (дата обращения: 12.01.2022).

8. Арестова Н.О., Рябчун И. О. Изменение вредоносности фитопатогенов в зависимости от метеорологических условий на виноградниках Нижнего Придонья // Плодоводство и ягодоводство. 2019. Т. 58. С.102-109. DOI: 10.31676/2073-4948-2019-58$102-108$.

9. Caffi T., Legler S.E.; González-Domínguez, E.; Rossi V. Effect of temperature and wetness duration on infection by Plasmoparaviticola and on post-inoculation efficacy of copper// European Journal of Plant Pathology, V.144, P. 737-750, 2016. DOI: 10.1007/s10658015-0802-9.» https://doi.org/10.1007/s10658-015-0802-9

10. Талаш А.И., Дробот К.О., Евдокимова Е.А. Прогноз развития болезней виноградной лозы в зависимости от условий вегетационного периода // Сборник материалов по основным итогам научных исследований за 2007 год. Краснодар: СКЗНИИСиВ, 2008. C. 302-306. 
11. Giuliana M, Toffolatti S. The Study of the Germination Dynamics of Plasmopara viticola Oospores Highlights the Presence of Phenotypic Synchrony With the Host. // Frontiersin Microbiology. 2021. 12. DOI: 10.3389/fmicb.2021.698586.

12. Buonassisi D., Colombo M., Migliaro D. et al. Breeding for grapevine downy mildew resistance: a review of "omics" approaches// Euphytica. 2017. V. 213, P. 103. DOI: $10.1007 / \mathrm{s} 10681-017-1882-8$

13. Якушина Н.А. Ощипок А.С. Эффективность защиты виноградной школки в зависимости от полевой выносливости сортов винограда к милдью // Магарач. Виноградарство и виноделие. 2015. № 3. С. 68-70.

14. Принципы создания эффективных биологических технологий защиты от вредных организмов / Е.П. Странишевская [и др.] // Современные технологии и средства защиты растений - платформа для инновационного освоения в АПК России: материалы конф. (8-12 октября 2018 г.). СПб., Пушкин, 2018. С. 150-152.

15. Gaforio L., Felix C, Muñoz-Organero G. Evaluation of resistance to downy mildew in grape varieties grown in a Spanish collection. // Vitis -Geilweilerhof. 2015. 54. P. 187-191.

16. Boso S, Alonso-Villaverde V, Santiago JL, Gago P, Martínez MC. Susceptibility of 44 grapevine (Vitis vinifera L.) varieties to downy mildew in the field. // Australian Journal of Grape and Wine Research. 2011. 17. P. 394-400. doi: 10.1111/j.1755-0238.2011.00157.x.

17. Fawke S., Doumane M., Schornack S. Oomycete interactions with plants: infection strategies and resistance principles// Microbiology and Molecular Biology Reviews 2015/. V 79(3), P. 263-280. doi:10.1128/MMBR.00010-15.

18. Недов П.Н. Новые методы фитопатологических и иммунологических исследований в виноградарстве // Кишинев: Наука, 1985. 138 с.

19. Талаш А. И. Методика проведения испытаний средств защиты против «сезонных» возбудителей болезней на виноградниках в полевых условиях. Краснодар: СКЗНИИСиВ, 2008. 12 с.

20. Методические рекомендации по применению фитосанитарного контроля в защите промышленных виноградных насаждений юга Украины от вредителей и болезней / Н.А. Якушина [и др.]. Симферополь: Полипресс, 2006. 24 с.

\section{References}

1. Shadura N.I., Stranishevskaya E.P., Volodin V.A. Vredonosnost' mild'yu i sortovaya ustojchivost' na sortah vinograda s razlichnoj stepen'yu vospriimchivosti v usloviyah yuzhnoberezhnogo agroklimaticheskogo rajona Respubliki Krym (Yug Rossii) // Problemy razvitiya APK regiona. 2016. №1 (25). Ch. 1. C. 95-99.

2. Yakushina N.A., Stranishevskaya E.P., Gyrenkova Ya.E., Skorikov A.S. Zashchita vinograda ot mild'yu, oidiuma, seroj gnili v gody epifitotijnogo razvitiya // Trudy nauchnogo centra vinogradarstva i vinodeliya. 2000. T. II, kn. 1. C. 69-76.

3. Gessler C., Pertot I., Perazzolli M. Plasmoparavitícola: a review of knowledge on downy mildew of grapevine and effective disease management // Phytopathologia Mediterranea. 2011. Vol. 50. P. 3-44.

4. Boso S., Gago P., Santiago J.-L., Fuente M. and etc. Affecting the Vineyard Populational Diversity of Plasmopara viticola // Plant Pathol J. 2019. 35(2). P.125-136/

5. Delmas C., Fabre F, Jolivet J, and etc. Adaptation of a plant pathogen to partial host resistance: selection for greater aggressiveness in grapevine downy mildew // Evolutionary Applications. 2016. V. 9. P. 709-725.

6. Li X., Yin L., Ma L. and etc. Pathogenicity variation and population genetic structure of Plasmopara viticola in China. Journal of Phytopathology. 2016. 164. P. 863-873. 
7. Arestova N.O., Ryabchun I.O. Razvitie fitopatogenov vinogradnyh rastenij v usloviyah Rostovskoj oblasti [Elektronnyj resurs] // Plodovodstvo i vinogradarstvo Yuga Rossii. 2016. № 42(6). S. 111-118. URL: http://journalkubansad.ru/pdf/16/06/11.pdf. (data obrashcheniya: 12.01.2022).

8. Arestova N.O., Ryabchun I. O. Izmenenie vredonosnosti fitopatogenov v zavisimosti ot meteorologicheskih uslovij na vinogradnikah Nizhnego Pridon'ya // Plodovodstvo i yagodovodstvo. 2019. T. 58. S.102-109. DOI: 10.31676/2073-4948-2019-58-102-108.

9. Caffi T., Legler S.E.; González-Domínguez, E.; Rossi V. Effect of temperature and wetness duration on infection by Plasmoparaviticola and on post-inoculation efficacy of copper// European Journal of Plant Pathology, V.144, P. 737-750, 2016. DOI: 10.1007/s10658015-0802-9. https://doi.org/10.1007/s10658-015-0802-9

10. Talash A.I., Drobot K.O., Evdokimova E.A. Prognoz razvitiya boleznej vinogradnoj lozy v zavisimosti ot uslovij vegetacionnogo perioda // Sbornik materialov po osnovnym itogam nauchnyh issledovanij za 2007 god. Krasnodar: SKZNIISiV, 2008. C. 302-306.

11. Giuliana M, Toffolatti S. The Study of the Germination Dynamics of Plasmopara viticola Oospores Highlights the Presence of Phenotypic Synchrony With the Host. // Frontiersin Microbiology. 2021. 12. DOI: 10.3389/fmicb.2021.698586.

12. Buonassisi D., Colombo M., Migliaro D. et al. Breeding for grapevine downy mildew resistance: a review of "omics" approaches // Euphytica. 2017. V. 213, P. 103. DOI: 10.1007/s10681-017-1882-8

13. Yakushina N.A. Oshchipok A.S. Effektivnost' zashchity vinogradnoj shkolki v zavisimosti ot polevoj vynoslivosti sortov vinograda k mild'yu // Magarach. Vinogradarstvo i vinodelie. 2015. № 3. S. 68-70.

14. Principy sozdaniya effektivnyh biologicheskih tekhnologij zashchity ot vrednyh organizmov / E.P. Stranishevskaya [i dr.] // Sovremennye tekhnologii i sred stva zashchity rastenij - platforma dlya innovacionnogo osvoeniya v APK Rossii: ma terialy konf. (8-12 oktyabrya 2018 g.). SPb., Pushkin, 2018. S. 150-152.

15. Gaforio L., Felix C, Muñoz-Organero G. Evaluation of resistance to downy mildew in grape varieties grown in a Spanish collection. // Vitis -Geilweilerhof. 2015. 54. P. 187-191.

16. Boso S, Alonso-Villaverde V, Santiago JL, Gago P, Martínez MC. Susceptibility of 44 grapevine (Vitis vinifera L.) varieties to downy mildew in the field. // Australian Journal of Grape and Wine Research. 2011. 17. P. 394-400. doi: 10.1111/j.1755-0238.2011.00157.x.

17. Fawke S., Doumane M., Schornack S. Oomycete interactions with plants: infection strategies and resistance principles// Microbiology and Molecular Biology Reviews 2015 / V 79(3), P. 263-280. doi:10.1128/MMBR.00010-15.

18. Nedov P.N. Novye metody fitopatologicheskih i immunologicheskih issledovanij v vinogradarstve // Kishinev: Nauka, 1985. 138 s.

19. Talash A. I. Metodika provedeniya ispytanij sredstv zashchity protiv «sezonnyh» vozbuditelej boleznej na vinogradnikah $\mathrm{v}$ polevyh usloviyah. Krasnodar: SKZNIISiV, 2008. $12 \mathrm{~s}$.

20. Metodicheskie rekomendacii po primeneniyu fitosanitarnogo kontrolya $\mathrm{v}$ zashchite promyshlennyh vinogradnyh nasazhdenij yuga Ukrainy ot vreditelej i boleznej / N.A. Yakushina [i dr.]. Simferopol': Polipress, 2006. 24 s. 